\title{
Shift in fungal communities and associated enzyme activities along an age gradient of managed Pinus sylvestris stands
}

\author{
Julia Kyaschenko ${ }^{1}$, Karina E Clemmensen ${ }^{2}$, Andreas Hagenbo ${ }^{2}$, Erik Karltun ${ }^{1}$ and \\ Björn D Lindahl ${ }^{1}$ \\ ${ }^{1}$ Department of Soil and Environment, Swedish University of Agricultural Sciences, Uppsala, Sweden and \\ ${ }^{2}$ Department of Forest Mycology and Plant Pathology, Uppsala BioCenter, Swedish University of Agricultural \\ Sciences, Uppsala, Sweden
}

\begin{abstract}
Forestry reshapes ecosystems with respect to tree age structure, soil properties and vegetation composition. These changes are likely to be paralleled by shifts in microbial community composition with potential feedbacks on ecosystem functioning. Here, we assessed fungal communities across a chronosequence of managed Pinus sylvestris stands and investigated correlations between taxonomic composition and extracellular enzyme activities. Not surprisingly, clear-cutting had a negative effect on ectomycorrhizal fungal abundance and diversity. In contrast, clear-cutting favoured proliferation of saprotrophic fungi correlated with enzymes involved in holocellulose decomposition. During stand development, the re-establishing ectomycorrhizal fungal community shifted in composition from dominance by Atheliaceae in younger stands to Cortinarius and Russula species in older stands. Late successional ectomycorrhizal taxa correlated with enzymes involved in mobilisation of nutrients from organic matter, indicating intensified nutrient limitation. Our results suggest that maintenance of functional diversity in the ectomycorrhizal fungal community may sustain long-term forest production by retaining a capacity for symbiosis-driven recycling of organic nutrient pools.
\end{abstract}

The ISME Journal (2017) 11, 863-874; doi:10.1038/ismej.2016.184; published online 13 January 2017

\section{Introduction}

Old-growth coniferous forests in Scandinavia are usually composed of trees of different species and ages, but today most forest areas are managed into even-aged stands, representing stages from clear cuts to mature forests. This has major effects on biodiversity and potential impacts on carbon (C) storage (Jandl et al., 2007). In uniform, young stands, undergrowth vegetation is markedly different from that in old stands (Hart and Chen, 2006), as is nutrient and water availability, soil microclimate, and litter quantity and quality (Jurgensen et al., 1997). These differences are likely to be paralleled by shifts in fungal community composition with potential feedbacks on $\mathrm{C}$ sequestration, nutrient cycling and plant production (Clemmensen et al., 2015). Since fungi dominate production of extracellular enzymes involved in organic matter decomposition in forest soils (Schneider et al., 2012; Eichlerová et al., 2015; Hesse et al., 2015), shifts in fungal

Correspondence: J Kyaschenko, Department of Soil and Environment, Swedish University of Agricultural Sciences, Lennart Hjelms väg 9, SE-75007 Uppsala, Sweden.

E-mail: iuliia.kyiashchenko@slu.se

Received 29 June 2016; revised 6 September 2016; accepted 7 November 2016; published online 13 January 2017 communities induced by management are, supposedly, reflected in the quantity and composition of enzymes.

In boreal forest soils the organic horizon becomes stratified, as fresh litter constantly is deposited on top of more decomposed organic matter. Different functional guilds of fungi have been shown to occupy spatially distinct vertical niches within the organic horizon (Baldrian et al., 2012; Clemmensen et al., 2015). In the litter layer, saprotrophic fungi are the principal decomposers of plant-derived litter, producing extracellular enzymes to degrade biopolymers and release metabolic resources. During decomposition, saprotrophic fungi retain and re-allocate nutrients within their mycelium and are, by this, able to overcome local nutrient limitation (Boberg et al., 2014). In the deeper, more decomposed humus layers, biotrophic mycorrhizal fungi dominate. Receiving carbohydrates from their plant host, ectomycorrhizal fungi generally have a reduced set of genes coding for plant cell wall-degrading enzymes (Kohler et al., 2015) and limited capacity for decomposition, as compared with free-lining saprotrophs. It has been proposed that saprotrophic and mycorrhizal fungi have overlapping fundamental niches, but that antagonistic mycorrhizal fungi exclude more efficient saprotrophic decomposers from deeper organic layers (Bödeker et al., 2016), and 
that competition between these fungal guilds might reduce decomposition rates (Gadgil and Gadgil, 1975; Averill and Hawkes, 2016; Fernandez and Kennedy, 2016).

Although mycorrhizal fungi in general are thought to be less efficient decomposers than saprotrophs, recent studies suggest that ectomycorrhizal fungi may still play an important role in organic matter transformation. Under strong nutrient limitation, with low mineralization and nutrients largely bound in complex organic forms, certain mycorrhizal fungi may use energy from host-derived sugars to power nutrient mobilisation from complex organic matter (Read and Perez-Moreno, 2003; Lindahl and Tunlid, 2015). Cortinarius species have been highlighted as particularly efficient in acquiring nutrients from organic pools, producing Mn-peroxidases, which are basidiomycetes-specific enzymes that facilitate oxidative decomposition of recalcitrant humus (Bödeker et al., 2014).

Clear-cutting has negative short-term effects on ectomycorrhizal fungal biomass and diversity (Jones et al., 2003; Grebenc et al., 2009) and leads to changes in fungal species composition (Hartman et al., 2012). Elimination of ectomycorrhizal fungi may open niches for saprotrophic fungi, proliferating in response to relaxed competition and increased resource availability (Lindahl et al., 2010; Averill and Hawkes, 2016; Bödeker et al., 2016). Furthermore, clear-cutting results in a flush of litter and dead fine roots and create favourable conditions for grasses and herbs, which together with increased variation in soil temperature, moisture and soil evaporation facilitate high rates of organic matter decomposition (Chatterjee et al., 2008). Such enrichment disturbance in combination with decreased competition for space and resources after harvesting - the 'Gadgil effect' (Gadgil and Gadgil, 1975; Fernandez and Kennedy, 2016) - may favour opportunistic saprotrophic species associated with ample production of hydrolytic enzymes involved in holocellulose decomposition (Moorhead and Sinsabaugh, 2006). In the absence of mycorrhizal fungi, saprotrophs may proliferate downward into relatively nitrogen $(\mathrm{N})$ rich, well decomposed organic matter, leading to increased $\mathrm{N}$ mineralization and contributing to the generally observed flush of inorganic $\mathrm{N}$ (Kreutzweiser et al., 2008) and C loss (Magnani et al., 2007) after clear-cutting.

On seedlings establishing after the clear-cut phase, a new generation of ectomycorrhizal fungi establishes, initially as a low-diversity community of nitrophilic, disturbance-adapted 'nursery species' (Dahlberg and Stenström, 1991; Wallander et al., 2010). Within the ectomycorrhizal fungal community, species within the Atheliaceae family have been found to dominate in younger stands (Twieg et al., 2007; Wallander et al., 2010; Sun et al., 2015), possibly adapted to the relatively high $\mathrm{N}$ availability (Taylor et al., 2000). As stands develop, re-establishment of the mycorrhizal fungal community may restore mycorrhizal competition with saprotrophs, reducing organic matter turnover. Nitrogen immobilisation in proliferating mycorrhizal mycelium may further intensify $\mathrm{N}$ limitation (Wallander et al., 2010; Näsholm et al., 2013) with a potential feedback on fungal community composition (Sterkenburg et al., 2015). Specifically, species that are efficient in organic nutrient acquisition, for example Cortinarius, may obtain a competitive advantage over less efficient Atheliaceae species, as $\mathrm{N}$ availability declines (Hobbie and Agerer, 2010; Deslippe et al., 2011; Bödeker et al., 2014).

In this study, we address the theoretical framework outlined above of how soil fungi and their enzyme production may respond to stand development in managed forests, and discuss the results in the context of $\mathrm{C}$ sequestration and nutrient cycling.

\section{We hypothesize that:}

(i) Ectomycorrhizal fungi will increase in abundance with increasing time since clear-cutting, whereas saprotrophs will decline and become increasingly restricted to the surface litter. Activities of cellulose degrading enzymes will correlate with saprotrophic fungal abundance.

(ii) Atheliaceae species will gradually be replaced by a more diverse ectomycorrhizal fungal community, increasingly dominated by Cortinarius species, in correlation with activities of enzymes involved in mobilization of organic nutrients.

To test these hypotheses, we selected 10 even-aged Pinus sylvestris stands with tree ages ranging from 1 to 158 years. We assessed community composition in different organic layers by high throughput sequencing of fungal ITS2 amplicons (Ihrmark et al., 2012; Lindahl et al., 2013) and investigated correlations between community shifts along the age gradient and activity patterns of extracellular enzymes (Saiya-Cork et al., 2002).

\section{Materials and methods}

\section{Study sites}

In early October 2012, samples were collected from 10 forest stands situated in Uppsala County, Sweden. The forest stands were all subjected to forestry, unfertilized and differed in stand age from recent clear-cuts to mature forests (Supplementary Table S1). The younger stands ( $<50$ years old) had been re-planted within 1-2 years after clear-cutting, while even aged structure of older stands $(>80$ years old) was obtained by selective thinning (the history of the 59-years-old stand is uncertain). The stands were dominated by Pinus sylvestris L. mixed with Picea abies L. with an understory of ericaceous dwarf shrubs (Vaccinium vitis-idaea L., Vaccinium uliginosum L. and Calluna vulgaris (L.) Hull), mosses (mainly Pleurozium schreberi 
(B.) Mitt.), and on young stand also grasses (primarily Deschampsia flexuosa L. and Festuca ovina L.). The stands were selected to be distant enough (at least $0.2 \mathrm{~km}$ apart) to be treated as independent replicates, but close enough (within $28 \mathrm{~km}$ distance) to avoid major differences in climate and geology.

\section{Soil sampling and analyses}

At each stand, nine soil cores ( $3 \mathrm{~cm}$ in diameter) were collected at random locations at least $5 \mathrm{~m}$ apart (Lilleskov et al., 2004), to avoid resampling of single individuals. Upon collection, all green plant parts were removed, and each core was split into three layers: litter $\left(\mathrm{O}_{\mathrm{i}}\right.$; slightly decomposed plant material), fragmented litter $\left(\mathrm{O}_{\mathrm{e}}\right.$; moderately decomposed plant material) and humus $\left(\mathrm{O}_{a}\right.$; highly decomposed plant material). Materials from respective layers were pooled within each stand, resulting in three pooled samples per stand. In total, 30 composite samples were analysed. After storage at $-20^{\circ} \mathrm{C}$, samples were finely ground in liquid $\mathrm{N}$ with mortar and pestle. Roots with a diameter of more than $2 \mathrm{~mm}$ were removed, whereas fine roots were retained. Subsamples were kept at $-20^{\circ} \mathrm{C}$ for enzyme analyses and the rest of the material was freeze-dried before DNA and ergosterol extractions. Extractable pools of inorganic $\mathrm{N}$, soil $\mathrm{pH}$ and organic content were determined on humus samples (a detailed description is provided in Supplementary Information, Section 1.1). All samples were subjected to ergosterol extraction (Nylund and Wallander, 1992; Supplementary Information, Section 1.2) and assayed for activities of selected hydrolytic enzymes: cellobiohydrolase $(\mathrm{CBH}), \quad \beta$-1.4-glucosidase (BG), $\beta$-1.4-xylosidase (BXD), leucine aminopeptidase (LAP), chitobiosidase (CHiB), $\beta-1.4-N$-acetylglucosaminidase (NAG), acid phosphatase $(\mathrm{aP})$ and oxidative enzymes: Mn-peroxidase and Laccase (Saiya-Cork et al., 2002; Supplementary Table S2; Supplementary Information, Section 1.3).

\section{Fungal community analysis}

DNA was extracted from $50 \mathrm{mg}$ of litter or 250-500 mg of fragmented litter or humus following the extraction protocol by Clemmensen et al. (2016) (Supplementary Information, Section 1.4). ITS2 amplicons were produced using the forward primer gITS7 (Ihrmark et al., 2012) and the two mixed reverse primers ITS4 (75\%; White et al., 1990) and ITS4arch $(25 \%$; 5'-CACACGCTGTCCTCGCCTTATT GATATGC-3') elongated with unique identification tags (Clemmensen et al., 2016). Products were mixed in equal concentrations and cleaned with the E.Z.N. A. Cycle Pure Kit (Omega Bio-Tek Inc., Nocross, GA, USA). Adaptor ligation and Pacific Biosciences PSII sequencing were performed by SciLifeLab (NGI, Uppsala, Sweden) using eight SMRT Cells.

\section{Sequence analysis}

Sequences were analysed using the bioinformatics pipeline SCATA (https://scata.mykopat.slu.se). After removal of sequences with mean quality $<20$ or containing bases with quality $<3$, sequences (complementary reversed, if needed) were searched for primers (requiring 90\% identity) and identification tags. Only sequences containing matching tags at both ends were retained. Sequences passing quality control were randomly down-sampled to equal sequencing depth (1238 sequences per sample). USEARCH (Edgar, 2010), as implemented in SCATA, was used to cluster sequences into species hypotheses (SHs) (Kõljalg et al., 2013) based on singlelinkage clustering with a $1.5 \%$ threshold distance for sequences to enter a $\mathrm{SH}$ and equal penalties for mismatch and gap extension. The UNITE reference sequence database (http://unite.ut.ee) was included in the clustering, in order to obtain identification of SHs. Sequence data are stored at NCBI (www.ncbi. nlm.nih.gov/sra) under the accession number SRP093592 (Supplementary Table S1). SHs were subjected to taxonomic and functional identification in order of decreasing global relative abundance, until at least $85 \%$ of the sequences in each sample were covered. Representative sequences from SHs were aligned and further analysed by neighbour joining with pairwise gap deletion in MEGA 6 (Tamura et al., 2013). Relative abundances were recalculated after removal of non-fungal sequences. SHs were further identified using the BLASTn algorithm against the UNITE database with neighbour joining trees as guidance and verification. Local SHs were assigned to UNITE SHs (if at least 98\% similar), or identified to genera or orders based on neighbour joining trees (if justified by boot strap support). Further, SHs were assigned to ecological functions based on taxonomic information or sequence similarity to available sequences (NCBI) obtained from well-defined substrates, such as cleaned roots or plant leaves (Clemmensen et al., 2013). The following functional groups were included: ectomycorrhizal, ericoid mycorrhizal, root ascomycetes (excluding known mycorrhizal taxa), litter ascomycetes, litter basidiomycetes, moulds (Morteriellales, Eurotiales, Capnodiales, Mucorales, Hypocreales), yeasts (Saccharomycetales, Cystofilobasidiales, Leucosporidiales, Sporidiobolales, Tremellales) and unknown (Supplementary Tables S3 and S4; Supplementary Figure S1).

\section{Statistical analysis}

The total fungal community data set was analysed using ordination methods in CANOCO 5 (Microcomputer Power, Ithaca, NY, USA). For graphical representation of variation in fungal community composition between forest stands, detrended correspondence analysis was implemented. Correlation between forest age and fungal community composition was evaluated for significance using canonical 
correspondence analysis (CCA) with Monte Carlo permutations (without permutations within plots to account for dependency between layers from the same plot). CCAs were conducted at the levels of SHs or genera/orders (genera and orders were combined in a single analysis due to taxonomic ambiguities at the finer phylogenetic levels of the same clades). In order to eliminate the expected effect of recent clear-cutting and focus on community changes in established stands, all CCAs were repeated with the two youngest stands ( 1 and 5 years old) excluded from the data set. Separate post-hoc CCAs were conducted for each organic layer as well as for each functional group.

Effects of forest age, organic layer and their interaction on relative abundances of functional groups, total amount of fungal biomass ( $\mu g$ ergosterol per $\mathrm{m}^{2}$ ) and biomass concentration ( $\mu$ g ergosterol per gram organic matter) were evaluated using mixed effect models within the nlme package in $\mathrm{R}$ version 3.1.3 (R Core Team, 2015). Age and layer were specified as fixed effects, whereas forest stand was included as a random factor. Tests were repeated with the two youngest stands excluded.

To analyse the effect of forest age on enzyme activities, a CCA with Monte Carlo permutations (without permutations within plots) was performed. In order to test correlations between variation in enzyme activities and variation in fungal community composition (genera/orders), simple Mantel tests were performed separately for each layer, using the $\mathrm{R}$ package ecodist (Goslee and Urban, 2007) and the Bray-Curtis index as dissimilarity metric. For each fungal $\mathrm{SH}$, a set of specific enzyme activities $E_{S, X}$ were calculated as abundance weighted averages across samples:

$E_{S, X}=\frac{\sum_{i=1}^{n} E_{X i} P_{i}}{\sum_{i=1}^{n} P_{i}}$,

where $E_{X i}$ is the activity of enzyme $\mathrm{X}$ in sample $i$, $P_{i}$ is the relative amplicon abundance of SHs in sample $i$ and $n$ is the total number of samples (Bödeker et al., 2014). Similarity in enzyme profiles between fungal genera/orders was visualised by principal component analysis of these specific enzyme activities (Equation 1). Only genera accounting for more than $1 \%$ of total amplicons in two or more samples were included. Post-hoc correlations between specific combinations of genera/orders (amplicon abundances) and enzyme activities were established using the $\mathrm{R}$ package Hmisc. To be comparable with fungal community data, which were expressed as relative abundances, enzyme data were expressed in relation to ergosterol concentrations and thereafter log transformed. Species data were arcsine transformed before all analyses (for calculation of specific enzyme activities, non-transformed relative abundance data were used).

\section{Results}

Soil characteristics

Soil pH ranged from 4.0 to 4.8 and decreased with increasing forest age $\left(r^{2}=0.54, P=0.01\right.$; Supplementary Table S1). Ammonium levels were highest in the two youngest stands and declined to low levels in stands above 12 years (Supplementary Table S1).

\section{Sequencing output}

In total, 101971 PacBio sequences passed quality control. After random subsampling and removal of plant sequences $(10 \%)$, the remaining 34048 sequences clustered into 1305 SHs, with each sample represented by on average 1135 sequences (range 868-1221). Out of this, 92\% of the sequences (458 SHs) were subjected to phylogenetic and functional identification.

\section{Community composition}

Fungal community composition was significantly affected by forest age both at the SHs and genera/ orders levels, with higher explanatory power at genera/orders level (Figure 1; Table 1). Significance remained after removal of the two youngest stands. Different layers were colonised by distinct fungal communities (Figure 1), and post-hoc CCAs on separate layers indicated that the relationship between community composition and forest age was strongest in the deepest humus layer and marginally insignificant in the litter layer (Table 1).

Functional groups segregated significantly between layers, confirming a preference of fungi a priori classified as litter-associated to surface litter, whereas root-associated taxa were predominantly found in

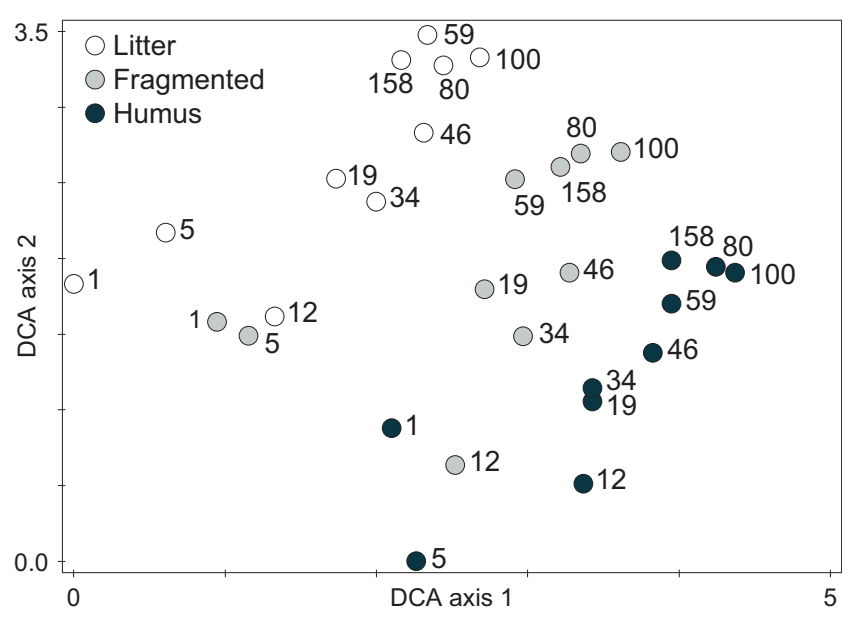

Figure 1 Variation in fungal community composition in different organic layers of 10 Pinus sylvestris forest stands of different ages (1-158 years), as visualised by a sample plot of a detrended correspondence analysis based on PacBio sequencing of amplified ITS2 markers. Numbers correspond to forest age; circles are shaded according to layers. Axes 1 and 2 explained 8 and $5.9 \%$, respectively, of the total inertia of 6.9 . 
Table 1 Effect of forest age on fungal community composition in organic layers of 10 Pinus sylvestris forest stands

\begin{tabular}{|c|c|c|c|c|}
\hline & \multicolumn{2}{|c|}{ 1-158 Years } & \multicolumn{2}{|c|}{ 12-158 Years } \\
\hline & $P$ & $\begin{array}{c}\text { Variation } \\
\text { explained (\%) }\end{array}$ & $\mathrm{P}$ & $\begin{array}{c}\text { Variation } \\
\text { explained (\%) }\end{array}$ \\
\hline \multicolumn{5}{|l|}{ SHs } \\
\hline All layers & 0.02 & 6 & 0.06 & 7 \\
\hline Litter & 0.07 & 14 & 0.1 & 18 \\
\hline Fragmented & 0.04 & 13 & 0.1 & 16 \\
\hline Humus & 0.02 & 14 & 0.01 & 17 \\
\hline \multicolumn{5}{|l|}{ Genera/orders } \\
\hline All layers & 0.03 & 10 & 0.04 & 9 \\
\hline Litter & 0.08 & 17 & 0.2 & 16 \\
\hline Fragmented & 0.07 & 17 & 0.2 & 18 \\
\hline Humus & 0.004 & 27 & 0.004 & 30 \\
\hline
\end{tabular}

The effect was evaluated by a canonical correspondence analysis (CCA) of all stands (1-158 years) or with the two youngest stands excluded (12-158 years). CCAs were conducted on species hypotheses (SHs) $(n=1305)$ or genera/orders $(n=66)$ on all layers (permutation blocked by plot) or separately within specific layers. Significant values $(P<0.05)$ are highlighted in bold.

fragmented litter and humus (Figures 2 and 3; Supplementary Figure S2; Table 2). Litter basidiomycetes declined in relative abundance with increasing forest age and litter ascomycetes were more strongly confined to the litter layer in older forests. Moulds and yeasts also declined in the humus layer with increasing forest age, but their overall relative abundance was low. Balancing the general decline in saprotrophs, ectomycorrhizal fungi increased in relative abundance with increasing stand age. The difference in functional guild dominance was most obvious between the two youngest stands ( 1 and 5 years) and the rest (12-158 years). However, the decline in litter basidiomycetes with increasing forest age remained significant after removal of the two youngest stands (Figure 2; Table 2).

Within litter ascomycetes, the most dominant orders were Venturiales and Rhytismatales (Lophodermium species), and litter basidiomycetes were strongly dominated by the genus Mycena. The effect of forest age on community composition within litter-associated fungi was marginally insignificant $(P=0.06$; Supplementary Table S5). Within the ectomycorrhizal fungal community, a significant effect of stand age was observed, both at the SHs and genera/orders levels and after removal of the two youngest stands (Supplementary Table S5). Piloderma and Tylospora (Atheliaceae) species dominated in younger stands (12-34 years) and Cortinarius and Russula species increased in relative abundance and became dominant in the oldest stands (over 100 years) (Figures 3 and 4; Supplementary Figure S1). The root ascomycete community was dominated by Archaeorhizomyces and Helotiales and changed significantly with increasing forest age. Mould composition was also significantly affected by forest age, but only at SHs level and when all stands were included (Figure 3; Supplementary Table S5).
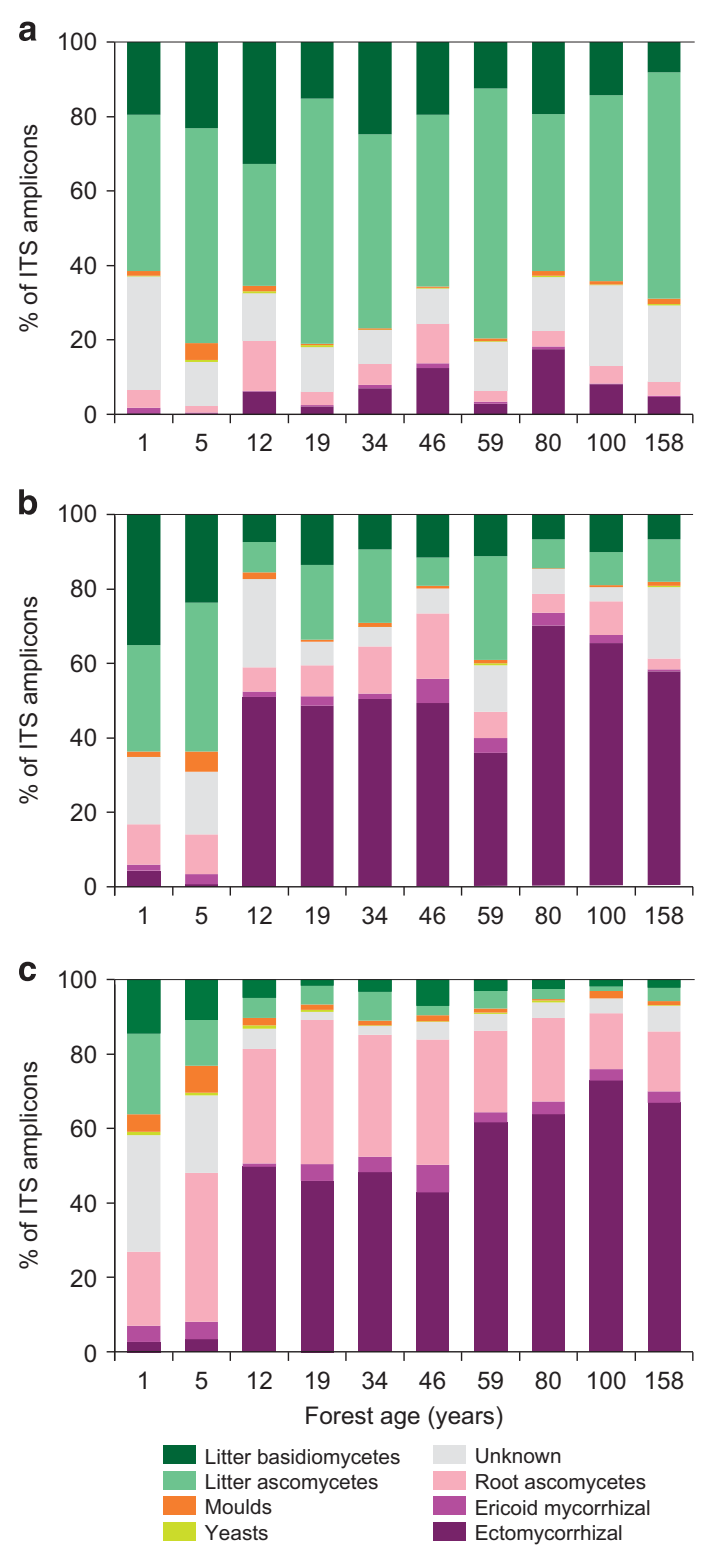

Figure 2 Distribution of fungal functional groups in different organic layers: (a) litter (b) fragmented litter (c) humus, of 10 Pinus sylvestris forest stands of different ages (1-158 years), as estimated by PacBio sequencing of amplified ITS2 markers. Abundances are given as percent of the identified amplicon sequences (accounting for $92 \%$ of total sequences).

Overall species richness and evenness declined significantly with increasing forest age in the humus layer, but only when tested across all forest stands (Figure 5a and c; Supplementary Table S6a). In contrast, ectomycorrhizal fungal richness and evenness in the humus and fragmented litter layers increased significantly with increasing forest age (Figure 5b; Supplementary Table S6b). For richness, the relationship was significant also with the two young stands excluded (Figure $5 \mathrm{~d}$ ).

Total amounts of fungal biomass ( $\mu \mathrm{g}$ ergosterol per $\mathrm{m}^{2}$ ) increased significantly with increasing forest age in the humus layer (Table 2; Supplementary 
Figure S3), whereas there was no significant effect on biomass concentration ( $\mu$ g ergosterol per gram organic matter).

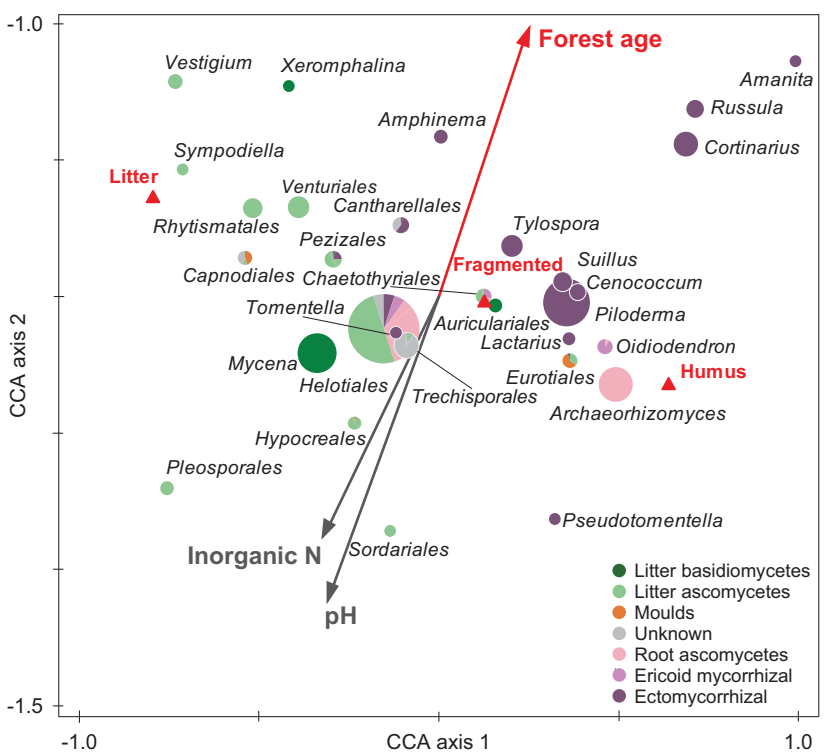

Figure 3 Distribution of fungal genera/orders in organic layers of 10 Pinus sylvestris forest stands of different ages (1-158 years), as visualised by a species plot of a canonical correspondence analysis (CCA) based on PacBio sequencing of amplified ITS2 markers. The CCA included 66 fungal genera/orders, but only the 30 most abundant genera/orders are shown. Circles are colourcoded according to functional groups with area indicating relative abundance. Triangles and the red vector represent constraining environmental variables, while grey vectors represent additional supplementary variables plotted in ordination space. Axes 1 and 2 explained 19.1 and $8.9 \%$, respectively, of the total inertia of 1.3 .

\section{Enzymes}

Enzyme activity profiles were not significantly correlated with forest age $(P=0.5)$. However, enzyme profiles correlated with fungal community composition (at genera/orders level) in the litter and fragmented litter, as indicated by significant Mantel statistics ( $r=0.46, P=0.02$ and $r=0.46, P=0.03$, respectively). In the humus layer, Mantel statistics indicated no significant correlation between enzymes and community matrices $(r=-0.4, P=0.9)$ and data were not further explored.

In litter, Cantharellales correlated positively with hydrolytic enzymes acting on polysaccharides (CBH, BG and $\mathrm{BXD}$ ) and $\mathrm{N}$-containing substrates (LAP and CiBH). The saprotrophic genera Pleosporales, Hypocreales and Trechisporales also correlated positively with $\mathrm{CBH}$ and $\mathrm{BXD}, \mathrm{CBH}$ and Laccase, respectively. Venturiales, on the other hand, correlated negatively with CBH, BG, BXD and LAP (Figure 6a; Supplementary Table S7a).

In fragmented litter, enzymes acting on polysaccharides were positively correlated with saprotrophs: Mycena (CBH, BG, BXD), Helotiales (CBH, $\mathrm{BXD}$ ) and Pleosporales (BXD). Nutrient-acquiring enzymes were positively correlated with ectomycorrhizal fungi: Cenococcum (aP), Piloderma (aP), Cortinarius (aP) and Russula (NAG), but negatively correlated with saprotrophs: Mycena (aP), Helotiales (aP), Pleosporales (aP, NAG) and Sordariales (NAG). Mn-peroxidase was positively correlated with Cortinarius but negatively with saprotrophic Rhytismatales (Figure 6b; Supplementary Table S7b).

Table 2 Results of linear mixed models

\begin{tabular}{|c|c|c|c|c|c|}
\hline & Forest age & Forest age $\times$ Fragmented & Forest age $\times$ Humus & Fragmented & Humus \\
\hline \multicolumn{6}{|l|}{$1-158$ years } \\
\hline Ectomycorrhizal & (+) 0.4 & (+) 0.02 & (+) 0.006 & (+) 0.0005 & (+) 0.0005 \\
\hline Ericoid mycorrhizal & $(-) 0.6$ & (+) 0.9 & (+) 0.8 & (+) 0.002 & (+) 0.0001 \\
\hline Root ascomycetes & $(-) 0.7$ & $(-) 0.4$ & $(-) 0.1$ & (+) 0.04 & $(+)<0.0001$ \\
\hline Litter ascomycetes & $(+) 0.4$ & $(-) 0.01$ & $(-) 0.01$ & $(-) 0.0002$ & $(-)<0.0001$ \\
\hline Litter basidiomycetes & $(-) 0.05$ & $(-) 0.9$ & (+) 0.9 & 0.2 & $(-) 0.0002$ \\
\hline Moulds & $(-) 0.8$ & $(-) 0.1$ & $(-) 0.02$ & $(+) 0.2$ & (+) 0.0006 \\
\hline Yeasts & $(-) 0.9$ & $(+) 0.2$ & $(-) 0.05$ & $(-) 0.007$ & (+) 0.04 \\
\hline Ergosterol, $\mu \mathrm{g} \mathrm{gOM}^{-1}$ & $(+) 0.6$ & (+) 0.7 & $(+) 0.6$ & (+) 0.4 & $(-) 0.4$ \\
\hline Ergosterol, $\mu \mathrm{g} \mathrm{m}^{-2}$ & $(-) 0.4$ & (+) 0.4 & $(+) 0.02$ & (+) 0.0003 & $(+)<0.0001$ \\
\hline \multicolumn{6}{|l|}{$12-158$ years } \\
\hline Ectomycorrhizal & (+) 0.7 & $(+) 0.3$ & (+) 0.07 & $(+)<0.0001$ & $(+)<0.0001$ \\
\hline Ericoid mycorrhizal & $(-) 0.8$ & $(-) 0.4$ & $(+) 0.8$ & (+) 0.001 & (+) 0.001 \\
\hline Root ascomycetes & $(-) 0.3$ & $(-) 0.8$ & $(-) 0.1$ & (+) 0.3 & $(+)<0.0001$ \\
\hline Litter ascomycetes & $(+) 0.4$ & $(-) 0.1$ & $(-) 0.09$ & $(-)<0.0001$ & $(-)<0.0001$ \\
\hline Litter basidiomycetes & $(-) 0.01$ & (+) 0.1 & (+) 0.1 & $(-) 0.003$ & $(-)<0.0001$ \\
\hline Moulds & (+) 0.2 & $(-) 0.2$ & $(-) 0.1$ & (+) 0.3 & (+) 0.02 \\
\hline Yeasts & $(-) 0.9$ & $(+) 0.3$ & $(-) 0.2$ & $(-) 0.04$ & $(+) 0.2$ \\
\hline Ergosterol, $\mu \mathrm{g} \mathrm{gOM}^{-1}$ & (+) 0.1 & $(-) 0.4$ & (+) 0.9 & (+) 0.02 & $(-) 0.8$ \\
\hline Ergosterol, $\mu \mathrm{g} \mathrm{m}^{-2}$ & $(-) 0.9$ & $(+) 0.9$ & (+) 0.1 & (+) 0.0004 & $(+)<0.0001$ \\
\hline
\end{tabular}

Effects of forest age, organic layer and their interactions on relative abundance of fungal functional groups and ergosterol in organic soil layers of 10 $(1-158$ years; $n=30)$ or $8(12-158$ years; $n=24)$ Pinus sylvestris forest stands. Significant values $(P<0.05)$ are highlighted in bold. Directions of the relationships are indicated in parentheses. 


\section{Discussion}

Ecosystem development may be described as driven by interactions between environmental conditions, composition of communities and their activities. These activities, in turn, have a major effect on the environment through feedback loops that may either stabilize ecosystems or lead to directional

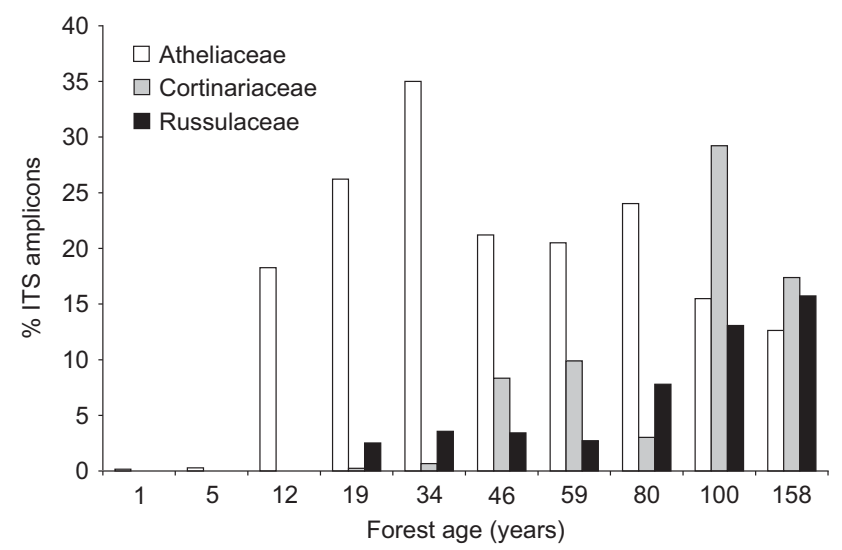

Figure 4 Distribution of the most dominant ectomycorrhizal fungal families in the humus layer of 10 Pinus sylvestris forest stands of different ages (1-158 years), as indicated by PacBio sequencing of amplified ITS2 markers. development. Fungal species are central mediators of these interactions (Lindahl and Clemmensen, 2016). In species, response traits (that determine population responses to environmental changes) are connected to effect traits (that determine how communities influence their environment; Koide et al., 2014). By combining molecular methods with enzyme analyses, we here demonstrate significant correlation between environmental drivers, fungal species and their enzyme expression leading towards a better mechanistic understanding of ecosystem responses to forestry-related disturbances. Clear-cutting radically altered fungal communities in pine forest soils, after which composition of species and functional groups changed progressively with increasing stand age (Figure 2). Data correlations supported that these compositional shifts were associated with changed effect traits, in terms of divergent enzyme activity profiles with presumed relevance for organic matter turnover (Figure 6).

In line with our first hypothesis (i), relative abundance and diversity of ectomycorrhizal fungi were negatively affected by clear-cutting but thereafter increased with increasing forest age (Figure 3; Table 2). In contrast, saprotrophs displayed high relative abundance right after harvest but subsequently declined, particularly in the deeper organic
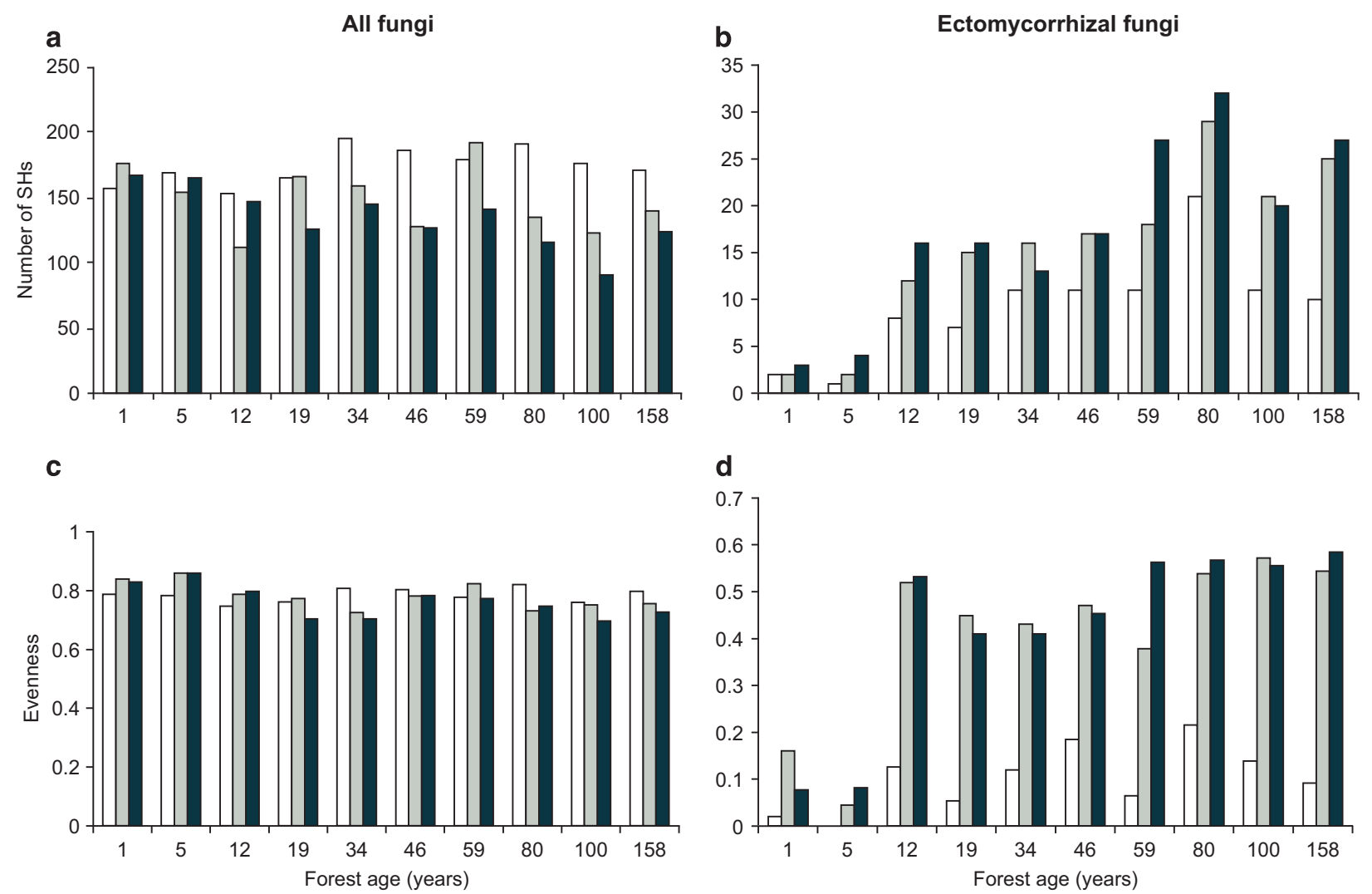

$\square$ Litter $\quad \square$ Fragmented $\quad$ Humus

Figure 5 Richness and evenness of total (a, c) and ectomycorrhizal (b, d) fungal communities in different organic layers of 10 Pinus sylvestris forest stands of different ages (1-158 years), as analysed by PacBio sequencing of amplified ITS2 markers. The indices were calculated on all fungal species hypotheses (SHs) $(n=1560)$ or on identified ectomycorrhial SHs $(n=78)$. 
870

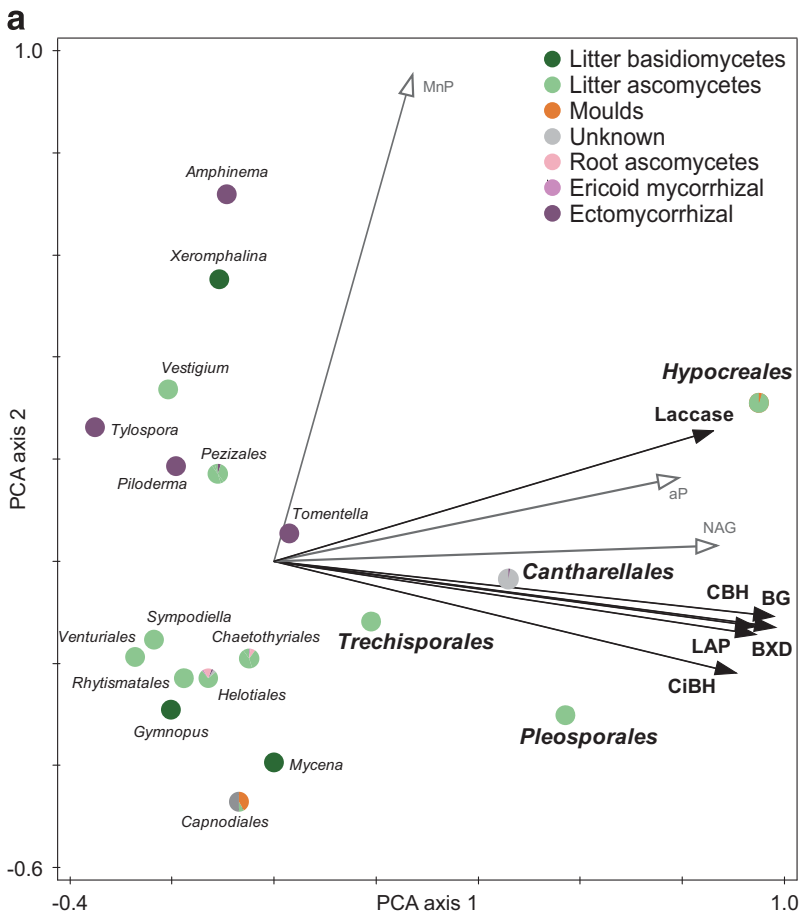

b

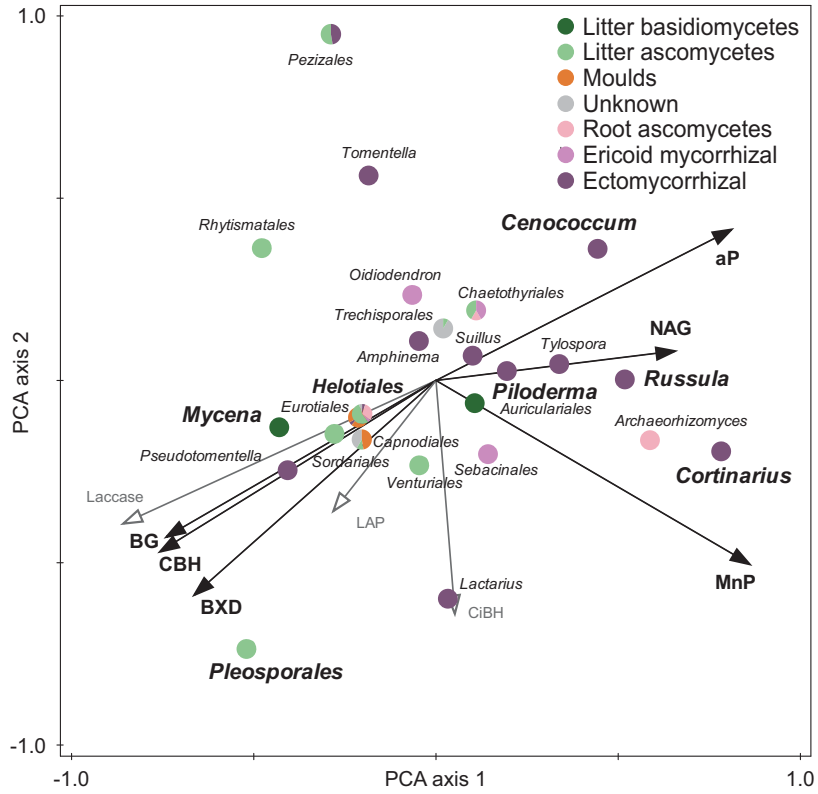

Figure 6 Similarity in enzyme profiles among fungal genera/ orders, based on principal component analysis of their specific enzyme activities, calculated as abundance weighted averages (according to formula 1). The figures are based on enzyme activity analyses and PacBio sequencing of amplified ITS2 markers from (a) litter and (b) fragmented litter of 10 Pinus sylvestris forest stands of different ages (1-158 years). Only genera accounting for more than $1 \%$ of total amplicons in two or more samples are shown. Genera/orders and enzymes with significant positive correlations (Supplementary Table S7) are highlighted by bold text and black vectors, respectively. aP, acid phosphatase; BG, $\beta$-1.4-glucosidase; BXD, $\beta-1.4$-xylosidase; $\mathrm{CBH}, \quad \beta$-D-cellobiohydrolase; $\mathrm{CiBH}$, chitobiohydrolase; LAP, leucine aminopeptidase; MnP, Mn-peroxidase; NAG, $\beta-1.4-N$ acetylglucosaminidase. layers (Figure 2; Table 2). Potentially, the observed decline of saprotrophic fungi could be relative rather than absolute (as a result of increasing abundance of ectomycorrhizal fungi). However, more or less stable ergosterol concentrations across the age gradient (Table 2) support that shifts in community composition can be interpreted in absolute terms. Moreover, the decline in overall fungal diversity in the humus layer with increasing forest age (Figure 5) further supports the picture that ectomycorrhizal fungi proliferate during stand development on the expense of other functional groups.

Elimination of ectomycorrhizal fungi by clearcutting opened a new niche for saprotrophic fungi (Figure 2), in line with the 'Gadgil effect' (Gadgil and Gadgil, 1975; Fernandez and Kennedy, 2016), which involves stimulated litter decomposition after severing of root connections and loss of ectomycorrhizal fungi. Presumed saprotrophs within Pleosporales and Hypocreales in the upper litter layer and Mycena in more decomposed litter correlated positively with enzyme activities involved in holocellulose and protein degradation (Figure 6a). These groups occurred more abundantly in younger stands (Figure 3), indirectly supporting that clear-cutting stimulated saprotrophic assimilation of carbohydrates and $\mathrm{N}$ from organic matter. Thus, ectomycorrhizal fungi and saprotrophs seem to have overlapping fundamental niches, but ectomycorrhizal fungi may restrict the realized niche of saprotrophs, repressing their decomposer activity under undisturbed conditions (Averill and Hawkes, 2016; Bödeker et al., 2016). Activated organic matter mineralization by saprotrophic fungi due to loss of mycorrhizal competition (that is, a 'Gadgil effect') in combination with improved plant litter quality might explain the high net $\mathrm{C}$ losses in forest ecosystems during the first decade after clear-cutting (Peltoniemi et al., 2004; Magnani et al., 2007).

After an almost complete loss of ectomycorrhizal fungal species as a result of clear-cutting, richness in the humus layer increased gradually for at least 60 years of stand development (Figure 5). These results are consistent with previous research (Wallander et al., 2010) and emphasize that ectomycorrhizal fungi are particularly sensitive to forestry. During the last 60 years, $95 \%$ of the Swedish forest area has been subjected to forestry practices involving clearcutting, and it is difficult to predict long-term effects on populations of ectomycorrhizal fungi in relation to preindustrial forest fire dynamics (Dahlberg, 2002). For example, species within the genus Cortinarius, frequently recorded as fruit-bodies in old-growth forests (Dahlberg, 2001), usually form long-lived and large individuals, which could make them particularly vulnerable to clear-cutting practices.

In agreement with our second hypothesis (ii), ectomycorrhizal fungal species composition (based on abundance of ITS markers) changed gradually throughout stand development from dominance by species within the Atheliaceae family (Piloderma 
and Tylospora species) at middle developmental stages to dominance by Cortinarius and Russula species in the oldest stands (Figures 3 and 4). Although not statistically testable, the fungal community in the 59-years-old stand still showed some similarity to younger stands (Figure 1). Swedish production forests are commonly subjected to repeated thinning during stand development, which could favour disturbance-adapted fungal communities also in older stands. In contrast, the oldest stands ( $>80$ years) in this study were never clearcut, and the longer-term effects of clear-cutting on fungal communities are not yet possible to evaluate.

Atheliaceae species arrived early (about 10 years after re-planting) and dominated the ectomycorrhizal fungal community in younger stands. The highest relative abundance of Atheliaceae was found in the 34-years-old stand, corresponding to timing of canopy closure (Croft et al., 2014), the highest standing biomass of fine roots (Konôpka et al., 2015) and maximum ecosystem C sink (Magnani et al., 2007). Athelioid species remained a significant component of the ectomycorrhizal fungal community also in older stands, but at lower relative abundance. Accelerated decomposition after clearcutting in combination with increased access of saprotrophs to low $\mathrm{C}: \mathrm{N}$ ratio substrates in deeper layers may have contributed to increased $\mathrm{N}$ mineralisation and elevated soil $\mathrm{pH}$ after clear-cutting (Smolander et al., 1998) compared with old forests (Supplementary Table S1). Furthermore, in the same age gradient, Hagenbo et al. (2016) observed higher rates of mycorrhizal mycelial production in the younger stands. Presumably, the combination of high resource availability, both in terms of hostderived $\mathrm{C}$ and inorganic $\mathrm{N}$, together with relaxed acidity stress favoured establishment of rapidly growing Atheliaceae species. Tylospora (Atheliaceae) species have previously been highlighted as favoured by high soil fertility (Parrent et al., 2006; Sterkenburg et al., 2015) and atmospheric N deposition (Taylor et al., 2000). Ammonium pools decreased during the first 12 years after stand re-establishment (Supplementary Table S1), but gross N mineralization could have remained high for longer time. Soil $\mathrm{pH}$ was elevated for about 50 years (Supplementary Table S1), and potentially contributed to the long-term effect of clear-cutting on fungal community composition and ectomycorrhizal fungal diversity. Further, priority effects (Kennedy et al., 2009) may have favoured persistence of successful early colonizers and prevented establishment of other species. Dispersal limitation has been shown to play an important role in short-term assembly of ectomycorrhizal fungal communities (Peay and Bruns, 2014), but it seems unlikely that low dispersal could have delayed re-establishment of certain ectomycorrhizal genera for decades within a patchy forest landscape.

High production of ectomycorrhizal mycelium in regenerating pine forests (Hagenbo et al., 2016) has been suggested to be associated with rapid $\mathrm{N}$ immobilization in fungal mycelium (Wallander et al., 2010), resulting in overall intensified $\mathrm{N}$ limitation of the ecosystem (Näsholm et al., 2013). Progressively increased competition for $\mathrm{N}$ combined with restored competitive suppression of saprotrophs by mycorrhizal fungi (Gadgil and Gadgil, 1975) may have hampered decomposition (Averill and Hawkes, 2016) and favoured accumulation of organic matter in the soil (Averill et al., 2014). In the long run, retention of nutrients in accumulating organic soil stocks leads to decreasing ecosystem productivity in the absence of disturbance (Magnani et al., 2007; Clemmensen et al., 2013), but mycorrhizal symbioses may enable plants to ameliorate $\mathrm{N}$ limitation, providing access to organic nutrient pools (Read, 1991).

Ectomycorrhizal taxa, such as species within the genera Cortinarius, Cenococcum and Russula, were positively correlated with activities of enzymes mobilising $\mathrm{N}$ and/or phosphorus from organic matter (Figure 6b). The correlation of the genus Cortinarius with lignin-degrading Mn-peroxidase in the fragmented litter confirms previous observations (Bödeker et al., 2014) and highlights these fungi as particularly important decomposers, facilitating mobilization of nutrients from complex organic matter (Lindahl and Tunlid, 2015). We postulate that successional establishment of ectomycorrhizal fungi with capacity to access more complex nutrient pools sustains plant productivity and delays ecosystem retrogression (Clemmensen et al., 2015; Baskaran et al., 2016).

Direct effects of forest age on enzyme activities did not receive statistical support. Further, a prokaryotic contribution to enzyme activities cannot be dismissed. Nevertheless, the significant correlations between stand age and fungal community composition, on the one hand, and fungal community composition and enzyme activities, on the other hand, suggest that enzyme activities shift during stand development in concert with fungal succession. Supposedly, our sampling was insufficient to capture this indirect effect of stand age on enzyme activity estimates, which are notoriously noisy due to spatial patchiness (Baldrian, 2014). The more direct causal links between environmental drivers and fungal communities, and between fungi and enzymes, may have provided more certain statistical support for these relationships in our study.

\section{Conclusion}

Here, we present relationships between fungal community dynamics and associated enzyme activities along an age gradient of managed pine forest stands. We propose that compositional shifts in fungal species and enzymes play an important role in regulating plant productivity and C storage during forestry rotation cycles. Clearly, clear-cutting has a major and longlasting influence on fungal diversity and its role in 
ecosystem processes. Potentially, alternative management regimes, such as continuous cover forestry, could limit harvest-associated losses of nutrient and organic matter stores by maintaining the competitive balance between saprotrophic and mycorrhizal fungi (that is, limit the 'Gadgil effect' associated with clear-cutting). Further, maintenance of functional diversity in the ectomycorrhizal fungal community (particularly preserving Cortinarius and Russula species) may sustain long-term forest production by retaining a capacity for symbiosis-driven recycling of organic nutrient pools throughout the forest rotation.

\section{Conflict of Interest}

The authors declare no conflict of interest.

\section{Acknowledgements}

This research was supported by the Swedish Research Council FORMAS (grant 2011-1747) to BDL. Bergvik Skog $\mathrm{AB}$ is gratefully acknowledged for providing study sites. We also thank three reviewers for their constructive comments which greatly improved the quality of the manuscript.

\section{Author contributions}

JK, KEC, AH, EK and BDL designed the study. JK, KEC and BDL conducted field sampling. JK performed the laboratory work and data analysis. JK wrote the first draft of the manuscript and all authors contributed substantially to data interpretations and revisions.

\section{References}

Averill C, Hawkes CV. (2016). Ectomycorrhizal fungi slow soil carbon cycling. Ecol Lett 19: 937-947.

Averill C, Turner BL, Finzi AC. (2014). Mycorrhizamediated competition between plants and decomposers drives soil carbon storage. Nature 505: $543-545$.

Baldrian P. (2014). Distribution of extracellular enzymes in soils: spatial heterogeneity and determining factors at various scales. Soil Sci Soc Am J 78: 11-18.

Baldrian P, Kolařík M, Štursová M, Kopecký J, Valášková V, Větrovský T et al. (2012). Active and total microbial communities in forest soil are largely different and highly stratified during decomposition. ISME $J$ 6: 248-258.

Baskaran P, Hyvönen R, Berglund SL, Clemmensen KE, Ågren GI, Lindahl BD et al. (2016). Modelling the influence of ectomycorrhizal decomposition on plant nutrition and soil carbon sequestration in boreal forest ecosystems. New Phytol; e-pub ahead of print 17 October 2016; doi:10.1111/nph.14213.

Boberg JB, Finlay RD, Stenlid J, Ekblad A, Lindahl BD. (2014). Nitrogen and carbon reallocation in fungal mycelia during decomposition of boreal forest litter. PLoS One 9: e92897.
Bödeker ITM, Clemmensen KE, de Boer W, Martin F, Olson Å, Lindahl BD. (2014). Ectomycorrhizal Cortinarius species participate in enzymatic oxidation of humus in northern forest ecosystems. New Phytol 203: $245-256$.

Bödeker ITM, Lindahl BD, Olson Å, Clemmensen KE. (2016). Mycorrhizal and saprotrophic fungal guilds compete for the same organic substrates but affect decomposition differently. Funct Ecol 30: 1967-1978.

Chatterjee A, Vance GF, Pendall E, Stahl PD. (2008). Timber harvesting alters soil carbon mineralization and microbial community structure in coniferous forests. Soil Biol Biochem 40: 1901-1907.

Clemmensen KE, Bahr A, Ovaskainen O, Dahlberg A, Ekblad A, Wallander $\mathrm{H}$ et al. (2013). Roots and associated fungi drive long-term carbon sequestration in boreal forest. Science 339: 1615-1618.

Clemmensen KE, Ihrmark K, Brandström-Durling $\mathrm{M}$, Lindahl BD. (2016). Sample preparation for fungal community analysis by high-throughput sequencing of barcode amplicons. In: Martin F, Uroz S (eds). Microbial Environmental Genomics (MEG). Springer: New York, NY, USA, pp 61-88.

Clemmensen KE, Finlay RD, Dahlberg A, Stenlid J, Wardle DA, Lindahl BD. (2015). Carbon sequestration is related to mycorrhizal fungal community shifts during longterm succession in boreal forests. New Phytol 205: 1525-1536.

Croft H, Chen JM, Noland TL. (2014). Stand age effects on boreal forest physiology using a long time-series of satellite data. For Ecol Manag 328: 202-208.

Dahlberg A. (2001). Community ecology of ectomycorrhizal fungi: an advancing interdisciplinary field. New Phytol 150: 555-562.

Dahlberg A. (2002). Effects of fire on ectomycorrhizal fungi in Fennoscandian boreal forests. Silva Fenn 36: 69-80.

Dahlberg A, Stenström E. (1991). Dynamic changes in nursery and indigenous mycorrhiza of Pinus sylvestris seedlings planted out in forest and clearcuts. Plant Soil 135: 73-86.

Deslippe JR, Hartmann M, Mohn WW, Simard SW. (2011). Long-term experimental manipulation of climate alters the ectomycorrhizal community of Betula nana in Arctic tundra. Glob Chang Biol 17: 1625-1636.

Edgar RC. (2010). Search and clustering orders of magnitude faster than BLAST. Bioinformatics 26: 2460-2461.

Eichlerová I, Homolka L, Žifčáková L, Lisá L, Dobiášová P, Baldrian P. (2015). Enzymatic systems involved in decomposition reflects the ecology and taxonomy of saprotrophic fungi. Fungal Ecol 13: 10-22.

Fernandez CW, Kennedy PG. (2016). Revisiting the 'Gadgil effect': do interguild fungal interactions control carbon cycling in forest soils? New Phytol 209: 1382-1394.

Gadgil RL, Gadgil PD. (1975). Suppression of litter decomposition by mycorrhizal roots of Pinus radiata. N Z J For Sci 5: 33-41.

Goslee SC, Urban DL. (2007). The ecodist package for dissimilarity-based analysis of ecological data. J Stat Softw 22: 1-19.

Grebenc T, Christensen M, Vilhar U, Čater M, Martín MP, Simončič P et al. (2009). Response of ectomycorrhizal community structure to gap opening in natural and managed temperate beech-dominated forests. Can J For Res 39: 1375-1386.

Hagenbo A, Clemmensen KE, Finlay RD, Kyaschenko J, Lindahl BD, Fransson P et al. (2016). Changes in 
turnover rather than production regulate biomass of ectomycorrhizal fungal mycelium across a Pinus sylvestris chronosequence. New Phytol; e-pub ahead of print 20 December 2016; doi:10.1111/nph.14379.

Hart SA, Chen HYH. (2006). Understory vegetation dynamics of North American boreal forests. Crit Rev Plant Sci 25: 381-397.

Hartmann M, Howes CG, VanInsberghe D, Yu H, Bachar D, Christen R et al. (2012). Significant and persistent impact of timber harvesting on soil microbial communities in Northern coniferous forests. ISME J 6: $2199-2218$

Hesse CN, Mueller RC, Vuyisich M, Gallegos-Graves LV, Gleasner CD, Zak DR et al. (2015). Forest floor community metatranscriptomes identify fungal and bacterial responses to $\mathrm{N}$ deposition in two maple forests. Front Microbiol 6: 337.

Hobbie EA, Agerer R. (2010). Nitrogen isotopes in ectomycorrhizal sporocarps correspond to belowground exploration types. Plant Soil 327: 71-83.

Ihrmark K, Bödeker ITM, Cruz-Martinez K, Friberg H, Kubartova A, Schenck J et al. (2012). New primers to amplify the fungal ITS2 region-evaluation by 454sequencing of artificial and natural communities. FEMS Microbiol Ecol 82: 666-677.

Jandl R, Lindner M, Vesterdal L, Bauwens B, Baritz R, Hagedorn $\mathrm{F}$ et al. (2007). How strongly can forest management influence soil carbon sequestration? Geoderma 137: 253-268.

Jones MD, Durall DM, Cairney JWG. (2003). Ectomycorrhizal fungal communities in young forest stands regenerating after clearcut logging. New Phytol 157: 399-422.

Jurgensen MF, Harvey AE, Graham RT, Page-Dumroese DS, Tonn JR, Larsen MJ et al. (1997). Impacts of timber harvesting on soil organic matter, nitrogen, productivity, and health of inland northwest forests. For Sci 43: 234-251.

Kennedy PG, Peay KG, Bruns TD. (2009). Root tip competition among ectomycorrhizal fungi: are priority effects a rule or an exception? Ecology 90: 2098-2107.

Kohler A, Kuo A, Nagy LG, Morin E, Barry KW, Buscot F et al. (2015). Convergent losses of decay mechanisms and rapid turnover of symbiosis genes in mycorrhizal mutualists. Nat Genet 47: 410-417.

Koide RT, Fernandez C, Malcolm G. (2014). Determining place and process: functional traits of ectomycorrhizal fungi that affect both community structure and ecosystem function. New Phytol 201: 433-439.

Konôpka B, Pajtík J, Marušák R. (2015). Biomass allocation influenced by canopy closure in a young spruce stand. J Forest Sci 61: 62-71.

Kreutzweiser DP, Hazlett PW, Gunn JM. (2008). Logging impacts on the biogeochemistry of boreal forest soils and nutrient export to aquatic systems: a review. Environ Rev 16: 157-179.

Kõljalg U, Nilsson RH, Abarenkov K, Tedersoo L, Taylor AFS, Bahram M et al. (2013). Towards a unified paradigm for sequence-based identification of fungi. Mol Ecol 22: 5271-5277.

Lilleskov EA, Bruns TD, Horton TR, Taylor DL, Grogan P. (2004). Detection of forest stand-level spatial structure in ectomycorrhizal fungal communities. FEMS Microbiol Ecol 49: 319-332.

Lindahl BD, Clemmensen KE. (2016). Fungal ecology in boreal forest ecosystems. In: Martin F (ed). Molecular
Mycorrhizal Symbiosis. John Wiley \& Sons, Inc.: Hoboken, New Jersey, NY, USA, pp 387-404.

Lindahl BD, de Boer W, Finlay RD. (2010). Disruption of root carbon transport into forest humus stimulates fungal opportunists at the expense of mycorrhizal fungi. ISME J 4: 872-881.

Lindahl BD, Nilsson RH, Tedersoo L, Abarenkov K, Carlsen T, Kjøller $\mathrm{R}$ et al. (2013). Fungal community analysis by high-throughput sequencing of amplified markers-a user's guide. New Phytol 199: 288-299.

Lindahl BD, Tunlid A. (2015). Ectomycorrhizal fungipotential organic matter decomposers, yet not saprotrophs. New Phytol 205: 1443-1447.

Magnani F, Mencuccini M, Borghetti M, Berbigier P, Berninger F, Delzon S et al. (2007). The human footprint in the carbon cycle of temperate and boreal forests. Science 447: 848-852.

Moorhead DL, Sinsabaugh RL. (2006). A theoretical model of litter decay and microbial interaction. Ecol Monogr 76: 151-174.

Nylund JE, Wallander H. (1992). Ergosterol analysis as a means of quantifying mycorrhizal biomass. Method Microbiol 24: 77-88.

Näsholm T, Höberg P, Franklin O, Metcalfe D, Keel SG, Campbell C. (2013). Are ectomycorrhizal fungi alleviating or aggravating nitrogen limitation of tree growth in boreal forests? New Phytol 198: 214-221.

Parrent JL, Morris WF, Vilgalys R. (2006). $\mathrm{CO}_{2}$-enrichment and nutrient availability alter ectomycorrhizal fungal communities. Ecology 87: 2278-2287.

Peay KG, Bruns TD. (2014). Spore dispersal of basidiomycete fungi at the landscape scale is driven by stochastic and deterministic processes and generates variability in plant-fungal interactions. New Phytol 204: 180-191.

Peltoniemi M, Mäkipää R, Liski J, Tamminen P. (2004). Changes in soil carbon with stand age-an evaluation of a modelling method with empirical data. Glob Chang Biol 10: 2078-2091.

R Core Team. (2015). R: a language and environment for statistical computing. R Foundation for Statistical Computing, Vienna, Austria.

Read DJ. (1991). Mycorrhizas in ecosystems. Experientia 47: 376-391.

Read DJ, Perez-Moreno J. (2003). Mycorrhizas and nutrient cycling in ecosystems: a journey towards relevance? New Phytol 157: 475-492.

Saiya-Cork KR, Sinsabaugh RL, Zak DR. (2002). The effects of long term nitrogen deposition on extracellular enzyme activity in an Acer saccharum forest soil. Soil Biol Biochem 34: 1309-1315.

Schneider T, Keiblinger KM, Schmid E, SterflingerGleixner K, Ellersdorfer G, Roschitzki B et al. (2012). Who is who in litter decomposition? Metaproteomics reveals major microbial players and their biogeochemical functions. ISME J 6: 1749-1762.

Smolander A, Priha O, Paavolainen L, Steer J, Mälkönen E. (1998). Nitrogen and carbon transformation before and after clear-cutting in repeatedly $\mathrm{N}$-fertilized and limed forest soil. Soil Biol Biochem 30: 477-490.

Sterkenburg E, Bahr A, Brandström-Durling M, Clemmensen KE, Lindahl BD. (2015). Changes in fungal communities along a boreal forest soil fertility gradient. New Phytol 207: 1145-1158. 
Sun H, Santalahti M, Pumpanen J, Köster K, Berninger F, Raffaello T. (2015). Fungal community shifts in structure and function across a boreal forest fire chronosequence. Appl Environ Microbiol 81: 7869-7880.

Tamura K, Stecher G, Peterson D, Filipski A, Kumar S. (2013). MEGA6: molecular evolutionary genetics analysis version 6.0. Mol Biol Evol 30: 2725-2729.

Taylor AFS, Martin F, Read DJ. (2000). Fungal diversity in ectomycorrhizal communities of Norway spruce [Picea abies (L.) Karst.] and beech (Fagus sylvatica L.) along North-South transects in Europe. In: Schulze ED (ed). Carbon and Nitrogen Cycling in European Forest Ecosystems. Springer-Verlag: Berlin, pp 343-365.
Twieg BD, Durall DM, Simard SW. (2007). Ectomycorrhizal fungal succession in mixed temperate forests. New Phytol 176: 437-447.

Wallander H, Johansson U, Sterkenburg E, BrandströmDurling M, Lindahl BD. (2010). Production of ectomycorrhizal mycelium peaks during canopy closure in Norway spruce forests. New Phytol 187: 1124-1134.

White TJ, Bruns T, Lee S, Taylor J. (1990). Amplification and direct sequencing of fungal ribosomal RNA genes for phylogenetics. In: Innis MA, Gelfand DH, Sninsky JJ, White TJ (eds). PCR Protocols: A Guide to Methods and Applications. Academic Press: New York, NY, USA, pp 315-322.

Supplementary Information accompanies this paper on The ISME Journal website (http://www.nature.com/ismej) 